\title{
Konstruksi Makna Aksi Massa 212 Bagi Wartawan Detik.com
}

\author{
Mohammad Fariansyah, Dadang Rahmat Hidayat, Achmad Abdul Basith \\ Fakultas Ilmu Komunikasi, Universitas Padjadjaran \\ Email: ryanrush16@gmail.com
}

\begin{abstract}
Islamic mass mobilization or 212 mass actions possess high news value for the mass media. Detik.com is a media that emphasizes a large portion in reporting mass actions 212. In the field, journalists of Detik.com receive sentiment and intimidation from the participants of the action. This study aims to determine the meaning of Detik.com journalists regarding mass actions 212. The experience of journalists involved as research subjects, revealed the motives, challenges, and meanings of Detik.com journalists. The research method used is qualitative with a phenomenological approach to identify the phenomenon from the perspective of the perpetrator. The analysis is also supported by direct observation on the actions of the Election Supervisory Agency (Bawaslu) and the escorting actions on the Constitutional Court (MK). The results show the presence of technical challenges, sentiments and intimidation in reporting; and journalists of Detik.com interpret 212 mass actions as coverage of mass actions with Islamic identity, coverage of political movements and coverage of peaceful actions. Conclusions from this study is the informants interpreted the mass action 212 based on intentional and awareness of the actions reflected from the coverage experience they went through.
\end{abstract}

Keywords: detik.com, islamic movement, journalist, mass action 212, phenomenology

\begin{abstract}
Abstrak
Aksi mobilisasi massa Islam atau aksi massa 212 memiliki nilai berita tinggi untuk diberitakan media massa. Detik.com merupakan media yang menaruh porsi besar dalam pemberitaan aksi massa 212. Dalam praktik lapangan, wartawan Detik.com mendapatkan sentimen dan intimidasi dari peserta aksi. Penelitian ini bertujuan untuk mengetahui pemaknaan wartawan Detik.com peliputan aksi massa 212. Pengalaman wartawan yang terlibat sebagai subjek penelitian, mengungkapkan tantangan dan pemaknaan wartawan Detik.com. Metode penelitian yang digunakan adalah kualitatif dengan pendekatan fenomenologi untuk mengetahui peristiwa dari sudut pandang pelaku. Analisis juga ditunjang dengan pengamatan langsung pada Aksi Bawaslu dan Aksi Kawal MK. Hasil penelitian menunjukan adanya tantangan teknis, sentimen dan intimidasi dalam peliputan; dan wartawan Detik.com memaknai aksi massa 212 sebagai peliputan aksi massa dengan identitas Islam, peliputan gerakan politik dan peliputan aksi damai. Simpulan dari penelitian ini adalah para informan memaknai aksi massa 212 berdasarkan kesengajaan dan kesadaran tindakan yang direfleksikan dari pengalaman liputan yang mereka lalui.
\end{abstract}

Kata kunci: aksi massa 212, detik.com, fenomenologi, gerakan islam, wartawan

\section{PENDAHULUAN}

Aksi massa 212 lahir usai gelombang Aksi Bela Islam dalam kasus penistaan agama oleh Basuki Tjahaja Purnama (BTP) pada 2016. Puncak dari aksi tersebut adalah munculnya Aksi Bela Islam pada 2 Desember 2016 (212) yang diklaim dihadiri jutaan peserta (Pratiwi, 2019). Aksi tersebut menjadi acuan penamaan kelompok Persaudaraan Alumni 212 (PA 212). Usai tuntas kasus Ahok, kelompok ini masih terus bergerak dengan sejumlah agenda massa seperti 'Aksi Bela Tauhid', 'Reuni 212', dan 'Munajat 212'.

Korespondensi: Mohammad Fariansyah, Fakultas Ilmu Komunikasi Universitas Padjadjaran, Jl. Raya Jatinangor Km-21, Kode Pos 45360, Email: ryanrush@gmail.com

Menyerahkan: Januari 2020, Diterima: Januari 2020, Terbit: Januari 2020

ISSN: 2549-0559 (cetak), ISSN: 2549-1946 (online), Website: http://jurnal.unpad.ac.id/kajian-jurnalisme 
Media mengambil peran dalam peliputan aksi massa 212 karena terdapat nilai berita tinggi dalam peristiwa tersebut. Terdapat dinamika dalam konteks pemberitaan media massa dan kerja-kerja jurnalistik. Dalam beberapa aksi, terjadi intimidasi kerja jurnalistik wartawan, misalnya yang menimpa wartawan Metro TV saat peliputan Aksi 212 dan intimidasi pada wartawan Detik.com saat meliput Munajat 212 (DH, 2016).

Hasil penelusuran awal peneliti dengan internet trail menemukan bahwa aksi massa 212 memiliki porsi peliputan di media massa. Temuan tersebut diperkuat laporan Tirto.id yang menyatakan bahwa Reuni 212 diberitakan oleh 86 surat kabar dan 55 media dalam jaringan (daring). Total berita Reuni 212 yang dilansir 86 surat kabar berjumlah 159 dan berita yang dilansir oleh media daring berjumlah 773. Unggahan media daring tersebut dilakukan dalam rentang waktu pukul 00:06 hingga 23:44 pada 2 Desember 2018. Detik.com menjadi portal berita daring yang melansir liputan Reuni 212 paling banyak dengan 71 berita.

Penelitian ini disusun untuk mengetahui konstruksi makna wartawan saat meliput aksi massa Islam. Pengalaman wartawan saat meliput Aksi Massa 212 menjadi objek untuk digali dalam penelitian ini lewat pendekatan fenomenologi. Pendekatan tersebut digunakan untuk mempelajari struktur tipe-tipe kesadaran yang membentuk struktur kesadaran yang pada akhirnya membuat makna dan menentukan isi dari pengalaman (content of experience) (Kuswarno, 2013). Dalam penelitian Aqmarina disebutkan bahwa terbangunnya kesadaran wartawan melalui beberapa tahap, diawali dengan memperoleh informasi dan pengetahuan tentang isu yang akan digarap, penyesuaian diri terhadap lingkungan sosial dan pekerjaan kejurnalistikan serta lingkungan sosial tempat peliputan. Proses tersebut kemudian membangun motif dan kesadaran seorang wartawan (Yanuary \& Gumilar, 2019). Selain itu, penelitian ini juga akan menggunakan teori konstruksi realitas Peter L. Berger \& Thomas Luckmann untuk membedah konstruksi wartawan terhadap Aksi Massa 212.

Pemilihan Detik.com dilakukan dengan pertimbangan bahwa Detik.com merupakan media online yang gencar memberitakan Aksi Massa 212 atau Aksi Bela Islam. Hal ini dibuktikan dengan studi Merlyna Lim lewat riset kuantitatifnya yang mengungkap bagaimana algoritma di media sosial menciptakan polarisasi dari kasus Ahok dan Aksi Bela Islam. Hasil dari studi tersebut menunjukkan pengguna media sosial aktif membagikan tautan tentang berita-berita yang muncul di media massa mengenai polemik BTP dan Aksi Bela Islam (Lim, 2017).

Selain itu, dua kasus yang berkaitan dengan intimidasi terhadap wartawan Detik.com saat peliputan gerakan massa juga mengindikasikan ada struktur makna dan pengalaman terkait peliputan Aksi Massa 212 dalam diri wartawan Detik.com. Aksi massa Islam, utamanya yang berlebel 212 berpotensi terjadi kedepannya sehingga penelitian ini masih relevan untuk dilakukan.

Penelitian ini ingin melihat bagaimana wartawan Detik.com memaknai aksi massa 212 dan kerja-kerja jurnalistik yang dilakukan saat meliput fenomena tersebut. Hasilnya diharapkan menjadi referensi wartawan lain dalam peliputan aksi yang memobilisasi massa Islam.

\section{METODE}

Penelitian ini disusun dengan rancangan metode penelitian kualitatif. Misi utama dari penelitian kualitatif adalah untuk memahami fenomena yang dialami manusia sebagai subjek penelitian. Peneliti dapat melakukan pengamatan pada aspek perilaku, persepsi, motivasi, tindakan, dan lainnya secara holistik yang kemudian di deskripsikan lewat kata-kata bahasa (Moleong, 2010).

Pendekatan yang digunakan dalam penelitian ini adalah pendekatan fenomenologi. Tugas utama dari pendekatan ini adalah untuk merekonstruksi kehidupan yang dialami manusia 
sebagai pelaku dalam realitas dunia. Dalam konteks, realitas memiliki sifat intersubjektif dalam artian individu dalam masyarakat saling berbagi pemaknaan mereka mengenai dunia (Kuswarno, 2013). Penelitian ini mencoba menelaah konstruksi makna wartawan Detik.com tentang realitas peliputan Aksi Massa 212.

Konstruksi makna wartawan Detik.com ditelaah menggunakan dua teori utama yakni konstruksi realitas Peter Berger \& Thomas Luckmann serta teori fenomenologi Alfred Schutz. Secara garis besar, Berger \& Luckmannn berbicara tentang proses eksternalisasi, objektivasi, dan internalisasi yang banyak berkaitan dengan proses sosialisasi primer dan sekunder. Sedangkan fenomenologi Alfred Schutz membantu menjelaskan fenomena dalam sudut pandang pelaku. Teori tersebut erat kaitannya dengan struktur pemaknaan, because motive (motif sebab), dan in-order to motive (motif supaya).

Empat informan dalam penelitian ini, selanjutnya kami sebut informan1 (Detiknews), informan2 (Detiknews), informan3 (20detik), dan informan4 (20detik), merupakan wartawan Detik.com yang pernah meliput aksi massa 212, dan sengaja diwawancarai untuk menggali pengalaman dan pemaknaan aksi massa 212. Selain itu peneliti juga melakukan observasi lapangan aksi massa 212 pada momentum Aksi Bawaslu (22 Mei 2019) dan Aksi Kawal MK (17 Juni 2019).

\section{HASIL DAN PEMBAHASAN}

Hasil penelitian ini mengungkapkan pengalaman dan makna yang dimiliki wartawan Detik.com atas penugasan lapangan yang diterima. Tiga hal tersebut mempengaruhi tindakan wartawan Detik.com dalam bekerja di lapangan saat meliput aksi massa 212. Pengalaman repetitif itu ditunjukan dengan adanya tanda-tanda yang dibuat wartawan dalam situasi peliputan tersebut.

Dalam menjalankan penugasan, wartawan juga mendapatkan tantangan peliputan yang berpengaruh pada struktur pengalaman wartawan tentang aksi massa 212. Terdapat tiga pengelompokan tantangan pengalaman yang akan dibahas pada penelitian yaitu; teknis kerja wartawan daring, sentimen massa kepada wartawan Detik.com dan pengalaman intimidasi kerja-kerja jurnalistik.

Pada aspek pemaknaan, peneliti menemukan adanya makna-makna yang dimiliki wartawan Detik.com terkait aksi massa 212. Para informan mengungkap tiga makna aksi massa 212 yaitu politik membawa agama (politik identitas), aksi yang mengalami pergeseran tujuan, dan aksi damai. Keempatnya juga mengungkapkan kesamaan bahwa makna yang mereka ungkapkan tidak mempengaruhi berita yang diproduksi. Mereka tetap bekerja sesuai sistem dan arahan koordinator liputan di kantor.

\section{Pengalaman Wartawan Detik.com Menghadapi Tantangan Peliputan Aksi Massa 212}

Keempat informan pernah mengalami tantangan teknis dalam peliputan aksi massa 212. Dari jawaban informan, peneliti membuat simpul-simpul tantangan yang dialami yakni mobilitas wartawan, kepekaan terhadap nilai berita, kebugaran fisik, kesulitan jaringan untuk berkomunikasi tuntutan untuk selalu bersiaga, dan pemahaman etika. Keempat tantangan teknis tersebut masing-masing dialami informan sesuai pengalamannya masing-masing.

Mobilitas menjadi tantangan yang dialami keempat wartawan. Jumlah massa yang banyak diakui mempersempit ruang gerak wartawan saat melakukan peliputan. Banyak tokoh hadir dengan waktu kedatangan yang tidak terduga membuat wartawan harus bergerak cepat untuk melakukan doorstop. Namun banyaknya massa yang duduk ataupun berdiri di jalanan membuat wartawan harus pandai menyelinap. Kadang wartawan kehilangan tokoh yang 
berpotensi menjadi sumber berita karena situasi tersebut.

Situasi tersebut dilihat langsung peneliti saat Aksi Kawal MK. Peneliti mengikuti informan 1 bekerja, dan pada satu waktu dia kecolongan berita dengan angle tertentu tentang Titik Soeharto karena pada saat bersamaan, dia mencari TNI yang membagikan nasi ke massa aksi. Informan 1 tidak mendapatkanya dan malah mendapatkan informasi dari rekannya bahwa Titik Soeharto hadir di lokasi. Informan1 lantas berjalan cepat diantara lautan massa untuk berpindah dari sisi lain.

Situasi tersebut berbenturan dengan tuntutan media daring untuk menyajikan informasi secara cepat. Informan 1 bekerja untuk Detik.com dan ia merupakan produk dari institusi Detik. com yang terbiasa dengan tuntutan menyajikan berita pendek dengan cepat. Pada akhirnya Informan1 memilih bertukar bahan rekaman atau transkip kepada sesama wartawan sehingga dia dapat tetap membuat berita. Namun karena tidak mengalami peliputan secara langsung, akurasi dan kecepatan berita yang diproduksi menjadi pertanyaan besar. Informan1 menyatakan bahwa yang terpenting adalah ia memberitakan peristiwanya.

Tantangan mobilitas wartawan mendapatkan tambahan tekanan dari ciri media daring yang menuntut kecepatan. Salah satu ciri media daring memang adalah kecepatan atau kesegeraan (immediacy) (Ward, 2002). Dalam praktiknya, kecepatan dalam memberitakan Aksi Massa 212 berbenturan dengan masalah akurasi saat wartawan memilih bertukar berita sesama wartawan agar tetap mendapatkan berita. Kecepatan dan akurasi bukan merupakan masalah baru di Indonesia (Margianto, J., \& Syaefullah, 2012). Hal tersebut nyatanya juga berlaku pada pemberitaan Aksi Massa 212.

Peneliti lantas melihat masalah konstruksi realitas wartawan terhadap kecepatan berpengaruh terhadap tantangan mobilitas dan bagaimana wartawan menyiasatinya. Berpijak pada tiga tahapan simultan eksternalisasi - objektivasi - internalisasi, peneliti mencoba menunjukan konstruksi wartawan Detik.com soal kecepatan. Berangkat dari motif sebab penugasan dan motif supaya melaksanakan tugas, wartawan Detik.com hadir datang ke lokasi aksi.

Saat melakukan peliputan, wartawan masuk dalam dunia intersubjektivitas dimana terjadi pertemuan antara dirinya dan pengetahuannya dengan realitas dan situasi massa aksi yang terinstitusi. Pada tahap objektivasi ini wartawan dihadapkan pada masalah mobilitas sehingga ia mencari solusi dengan bertukar berita. Kantor tidak mempersalahkan hal tersebut dan berita naik. Dari situasi tersebut dapat dilihat bahwa Detik.com menuntut kecepatan dan jika tidak dapat pertama, setidaknya tidak ketinggalan berita. Hal itu lantas diinternalisasikan kedalam diri peneliti dan berpengaruh pada caranya meliput pada situasi yang serupa.

Mobilitas merupakan tantangan yang dikemukakan oleh keempat informan. Peneliti melihat konstruksi soal kecepatan tersebut juga bekerja pada tiga wartawan lainnya dengan referensi pengalaman yang berbeda. Terkait mobilitas, peneliti merujuk pendapat Informan3 tentang tantangan kebugaran fisik. Selain harus berpindah-berpindah dan menerobos massa, peliputan Aksi Massa 212 juga tertantang oleh medan di lapangan. Sering kali Aksi Massa 212 dilaksanakan pada siang hari yang menguras tenaga. Wartawan yang telah beberapa kali meliput lantas melakukan eksternalisasi atau penyesuaian berdasarkan cadangan pengetahuan yakni dengan menggunakan pelindung kepala dan membawa persediaan air lebih saat di lapangan.

Tantangan lainnya yang masih berkaitan dengan mobilitas dan kebugaran fisik adalah tantangan untuk berjaga atau standby. Wartawan harus berjaga di tempat peliputan dari acara mulai sampai selesai, bahkan sedari malam sebelumnya. Informan4 dan Informan 2 menyebut standby sebagai tantangan berkaitan dengan lamanya durasi peliputan yang menuntut wartawan diam di tempat. Dengan sistem kerja di Detik.com yang memusatkan arahan di kantor, maka 
wartawan tidak dapat pulang sebelum ada arahan kantor.

Tantangan selanjutnya adalah kepekaan terhadap nilai berita yang menarik. Dalam proses peliputan di lapangan, wartawan bekerja atas motif sebab dan supaya yakni berkaitan dengan penugasan kantor. Dalam praktiknya, wartawan mendapatkan arahan untuk mencari beritaberita yang menarik untuk diberitakan. Hal tersebut juga berlaku dalam konteks peliputan Aksi Massa 212. Wartawan Detik.com mendapatkan arahan untuk mencari berita-berita yang menarik terkait massa aksi.

Perintah mencari berita yang menarik lantas diterjemahkan wartawan menurut cadangan pengetahuan yang dimiliki dari peliputan sebelumnya. Dari jawaban para informan, terlihat bahwa nilai berita menarik yang diproduksi berorientasi pada click (clickbait) pengunjung. Informan4 memberikan contoh saat meliput aksi 21-22 Mei dimana berita yang dicarinya merupakan berita dengan angle menarik, narasi tidak masalah berbeda asal sesuai fakta.

Dengan berita begini bisa gak nih minimal orang ngelihat, ngeklik, minimal clickbait ini berita sehingga dapat pemasukan dari iklan. Itu sebenarnya tujuannya makanya dibikin angle yang semenarik mungkin misalnya kayak rusuh 21-22. Aksi 21-22 di Bawaslu rusuh, itu angle 1, kalau media lain kan bisa bikin ormas Islam yang di Bawaslu tiba-tiba rusuh. Anglenya kan beda tapi sama intinya, mungkin yang 21-22 rusuh ormas Islamnya dimasukin ke badan berita kalau yang tadi dibalikin tanggal 21-22 nya dimasukin ke badan berita kemudian ormas Islamnya ditaruh dijudul. (Informan4 Ramadan Alhakki, 2019)

Pemahaman bahwa berita Detik.com merupakan berita yang menarik didapatkan dari penugasan peliputan yang repetitif. Seperti yang dijelaskan sebelumnya, sistem kerja Detik. com sangat terpusat pada koorlip kantor. Wartawan harus selalu berkoordinasi dan menyajikan berita dengan cepat, wartawan Detik.com harus bisa menemukan berita yang menarik di lapangan. Menarik menurut Detik.com adalah yang dapat mendapatkan click banyak. Pada dunia intersubjektif, wartawan akhirnya mengenal produk berita yang menarik tersebut pada saat objektivasi.

Menarik memang merupakan salah satu nilai berita. Namun memusatkan kerja jurnalistik pada nilai berita menarik yang berorientasi clickbait memunculkan permasalahan tersendiri yakni abainya wartawan pada prinsip-prinsip jurnalistik. Dengan argumen yang diungkapkan Informan4 misalnya, dimana ia menyebut bahwa mengubah angle menjadi lebih menarik tidak masalah asalkan intinya sama. Hal itu bertentangan dengan prinsip jurnalistik yang berakibat berita bisa disalahpahami oleh masyarakat. Apalagi dalam iklim media daring yang mengutamakan berita update yang cepat. Dari pernyataan Informan4 peneliti setidaknya melihat tiga pengabaian pada tanggung jawab pada kebenaran, loyalitas kepada publik, dan disiplin verifikasi (Kovach, B., \& Rosentiel, 2001).

Tantangan teknis selanjutnya adalah tantangan koordinasi dan pengiriman berita ke kantor karena susah jaringan internet. Pada peliputan Aksi Massa 212 wartawan dihadapkan pada situasi dimana sinyal menjadi barang langka. Situasi tersebut berkaitan dengan jumlah peserta dalam satu Aksi Massa 212 yang bisa bervariasi dari ribuan hingga puluhan ribu bahkan ada klaim bahwa peserta aksi mencapai angka hingga jutaan pada aksi 212 (2016) (Pratiwi, 2019). Peneliti juga mengalami permasalahan yang sama saat melakukan observasi pada peliputan Aksi Bawaslu dan Aksi Kawal MK.

Susah jaringan berpengaruh pada kerja wartawan di lapangan. Para informan mengaku sulit dalam berkoordinasi dengan kantor dan mengirimkan data menggunakan jaringan internet. Dalam kondisi tersebut wartawan tetap dituntut untuk mengirim berita dengan cepat meski ada pemakluman dari kantor. Kecepatan tetap menjadi tuntutan utama, dimana Informan1 menceritakan bahwa meskipun susah jaringan internet untuk mengirimkan data, tapi ada 
tuntutan bagi wartawan untuk mengirimkan data sesegera mungkin.

Terdapat dua siasat yang dilakukan wartawan dalam situasi tersebut. Pertama, untuk berkoordinasi dengan kantor atau wartawan lain, informan menggunakan telepon genggam biasa tanpa jaringan internet. Kedua, untuk mengirimkan data, diambil langkah menjauh dari kerumunan massa aksi untuk mencari ruang kosong. Ketika menjauh, wartawan mendapatkan kembali sinyal internet dan mengirimkan data. Langkah menjauh dari kerumunan berkaitan dengan tantangan mobilisasi yang telah disebutkan sebelumnya. Wartawan harus bergerak maju-mundur untuk mengamankan bahan berita dan mengirimnya. Hal tersebut juga turut mempengaruhi stamina wartawan di lapangan.

Dalam teori konstruksi realitas, pengalaman-pengalaman tersebut muncul pada tahapan objektivasi dimana cadangan pengetahuan wartawan bertemu dengan produk-produk manusia di dunia intersubjektif. Keempatnya memiliki hasil internalisasi dan pemahaman yang berbedabeda dalam memandang tantangan teknis tersebut. Hal tersebut terlihat dari bagaimana setiap informan bekerja di lapangan. Informan4 dan Informan2 bekerja dengan lebih tenang karena memiliki banyak cadangan pengetahuan sehingga mereka bisa memilih tindakan yang tepat, misal dalam konteks tantangan kepekaan terhadap berita yang menarik. Informan 4 dan Informan2 tidak mengambil semua potensi yang menarik, namun mereka memiliki saringan terhadap berita tertentu yang memang menarik. Berbeda dengan Informan3 dan Informan1 yang terlihat lebih mobile di lapangan, keduanya bergerak mengikuti sumber berita yang dianggap menarik. Hal tersebut yang membuat Informan3 menyebut stamina sebagai salah satu tantangan teknis peliputan Aksi Massa 212.

Selanjutnya adalah tantangan menghadapi sentimen massa 212 terhadap wartawan Detik. com. Keempat informan merasakan adanya sentimen ini dalam proses peliputan Aksi Massa 212. Berdasarkan wawancara dan pengamatan pada informan, kata sentimen yang dimaksud merujuk pada perasaan berlebih-lebihan terhadap sesuatu. Wartawan Detik.com kerap dianggap memelintir berita oleh massa aksi.

Sebagai gambaran, peneliti mencontohkan sentimen yang didapat Informan4 saat meliput Aksi Kawal MK. Saat itu, ia secara langsung diingatkan oleh peserta aksi untuk tidak memelintir berita saat akan mewawancarai seorang nenek. Informan4 yang saat itu tengah bersama rekannya wartawan Liputan6 merasakan perbedaan perilaku dimana temannya tidak mendapatkan sentimen tersebut.

Cerita mirip juga diceritakan Informan2 saat akan mewawancarai Neno Warisman, tokoh Massa 212. Neno menolak diwawancara oleh Informan2 karena statusnya sebagai wartawan Detik.com, sementara itu saat rekannya yang berasal dari Kumparan diperbolehkan untuk wawancara. Informan3 mengalami hal yang sama, dimana ia mengaku ditolak saat akan mewawancarai massa aksi. Informan1 mengaku tidak pernah merasakannya secara langsung, namun mengetahui sentimen tersebut dari obrolan sesama wartawan.

Menurut Informan2, sentimen massa aksi 212 berawal dari Aksi 411 pada tahun 2016. Saat itu, massa aksi melakukan penginjakan rumput sekitar Monas dan Balai Kota Jakarta hingga rusak parah. Saat itu, keindahan dan tata kota termasuk rumput merupakan perhatian pemerintah provinsi DKI Jakarta. Detik.com dalam bahasa Informan2 menghantam massa aksi dengan pemberitaan yang terus menerus tentang penginjakan rumput tersebut. Dari situlah menurut Informan2 mulai timbul sentimen terhadap wartawan Detik.com karena dianggap membuat berita negatif bagi massa aksi.

Sentimen tersebut berpengaruh pada kerja peliputan wartawan Detik.com pada saat Aksi Massa 212. Dalam proses peliputan, para informan dengan sengaja menyesuaikan diri dengan massa aksi 212. Penyesuaian meliputi cara berpakaian, berperilaku, dan dengan sengaja 
menyembunyikan kartu pers saat peliputan. Mereka juga mementingkan keselamatan diri karena adanya sentimen bisa berimplikasi pada tindakan intimidatif massa terhadap wartawan.

Penyesuaian dilakukan informan secara sadar karena pengetahuan terkait sentimen massa aksi terhadap wartawan Detik.com. Saat meliput aksi massa 212, wartawan mengenakan baju muslim dan atribut yang menyerupai massa aksi. Informan 2 mengaku sengaja membeli atributatribut dari massa aksi yang berjualan. Secara perilaku, para informan sengaja berperilaku sesuai dengan massa aksi, misalnya saat massa aksi berdoa maka informan ikut mengangkat tangan. Terakhir para informan mengaku selalu menyembunyikan kartu pers mereka karena takut akan dipotret oleh massa aksi dan disebarluaskan di media sosial.

Tahapan penyesuian tersebut merupakan tahapan eksternalisasi informan yang menyesuaikan diri dengan dunia sosio-kultural sebagai produk manusia (Berger, P. L., \& Luckmann, 1990). Dunia sosiokultural dalam konteks ini adalah massa aksi 212. Penyesuaian diri berdasarkan cadangan pengetahuan yang kemudian memunculkan tiga tindakan pada cara berpakaian, berperilaku, dan menyembunyikan kartu pers.

Kesadaran akan adanya sentimen terhadap wartawan Detik.com ditanggapi kantor dengan arahan untuk mementingkan keselamatan diri dalam peliputan. Arahan keselamatan diri tersebut juga menjadi motif sebab wartawan melakukan penyesuaian diri terhadap massa aksi. Namun bukan berarti wartawan dilepaskan tanggung jawab dari liputan. Wartawan yang bertugas harus bisa mengirimkan berita dengan angle menarik kepada kantor.

Tantangan selanjutnya adalah terjadinya intimidasi terhadap wartawan Detik.com. Merujuk pada Asosiasi Jurnalis Independen (AJI) yang mengakategorikan intimidasi menjadi dua yakni intimidasi verbal dan non-verbal (fisik). Diantara keempat informan, hanya Informan3 yang pernah mengalami intimidasi secara fisik. Sisanya pernah menjadi saksi adanya intimidasi fisik terhadap wartawan.

Intimidasi fisik yang diterima Informan3 terjadi saat gelaran Munajat 212. Saat itu Informan3 mendapat kekerasan fisik usai mencoba mengabadikan momen tertangkapnya pencopet di kerumunan massa. Kejadian tersebut berujung pelaporan Detik.com ke pihak kepolisian. Informan3 sempat diistirahatkan selama beberapa minggu. Lain hal dengan Informan2 yang menceritakan pengalamannya menjadi saksi intimidasi. Saat itu, dia bertugas meliput Aksi Bela Tauhid bersama rekannya Rolando yang merupakan wartawan muda. Rolando mendapatkan intimidasi saat tengah mengorek sampah untuk mencari bungkus nasi bergambar Prabowo - Sandi. Ia lantas mendapatkan intimidasi hingga foto kartu persnya diunggah ke dunia maya. Mereka menganggap Rolando tengah mencari kejelekan massa aksi. Menurut penjelasan Informan2, Rolando mengorek sampah atas perintah kantor.

Informan1 pernah menjadi saksi kekerasan pada wartawan saat peliputan Aksi Bawaslu 21 - 22 Mei. Peneliti hadir dalam peristiwa tersebut dan melakukan observasi pada kerja Informan4. Aksi berjalan damai dari siang sampai waktu Salat Isya', massa menyampaikan aspirasinya dengan tertib di belakang pagar berduri. Situasi berubah usai massa aksi damai bubar, kerusuhan terjadi antara massa dengan pihak kemanan. Kerusuhan memang lantas dikonfirmasi oleh polisi sebagai ulah dari perusuh yang terencana (CNN, 2019).

Wartawan berada di sisi yang sama dengan polisi. Saat bersama polisi itulah Fahri melihat polisi melakukan intimidasi terhadap wartawan. Kejadian tersebut terjadi ketika polisi melarang wartawan mengambil polisi yang melakukan kekerasan pada perusuh atau massa aksi yang tertangkap. Seorang wartawan mengangkat telepon genggam seperti akan mengambil gambar. Gelagat wartawan tersebut membuat polisi bergerak dan melakukan intimidasi kepada wartawan.

Situasi yang dialami Informan3, kesaksian Informan2 dan Informan1 masing-masing 
memiliki konteks yang berbeda. Namun paparan tersebut menunjukan intimidasi pada wartawan pada konteks peliputan aksi massa Islam bisa berasal dari massa atau dari aparat pengamanan. Situasi massa dapat seketika berubah menjadi rusuh dengan hadirnya provokator. Saat Aksi Bawaslu peneliti melihat sendiri bagaimana provokator bekerja membakar emosi massa untuk merubah aksi menjadi kerusuhan. Aparat pengamanan lantas melihat untuk mengambil langkah tindakan terhadap massa dan tidak berkenan untuk dipublikasi. Tindakan intimidasi pada kerjakerja jurnalistik merupakan bentuk pelanggaran terhadap kebebasan pers yang memang masih memiliki lapor merah (RSF, 2019).

Dalam konteks ini, muncul permasalahan dalam sisi pengetahuan wartawan pada peliputan Aksi Massa 212 yang berubah menjadi rusuh. Apa yang harus dilakukan wartawan pada situasi tersebut merupakan pertanyaan utama. Para informan mengaku setelah hadirnya sentimen kepada wartawan Detik.com mereka mendapatkan instruksi untuk mementingkan keselamatan diri saat peliputan aksi massa 212. Namun hal tersebut tidaklah cukup, karena media harus membekali wartawan dengan SOP (Standard Operational Procedure) yang jelas bagaimana menghadapi peliputan aksi massa yang berubah jadi rusuh (Madrim, 2019).

Nah salah satu yang bisa dibilang kelemahan mungkin di perusahaan media itu kalau mau menerjunkan si wartawan ke lapangan itu dia sudah punya data yang cukup misalkan tentang potensi akan terjadinya kekerasan dan sebagainya. Kemudian ketika sudah terjadi kekerasan sejauh mana jurnalis ini akan dilarikan kemana dan itu yang belum ada SOP hampir di sebagian besar perusahaan media tidak memiliki SOP terkait kekerasan terhadap jurnalis. Jadi pas malam Informan3 itu mengalami kekerasan saya juga sedang ada di lapangan waktu itu. Saya di lapangan bersama teman dari CNN juga yang jadi korban terus kemudian saya ikut mendampingi Informan3. (Madrim, 2019)

Tabel 1. Pengalaman Wartawan detik.com menghadapi peliputan Aksi Massa 212

\begin{tabular}{|c|c|c|c|}
\hline \multirow{2}{*}{ Informan } & \multicolumn{3}{|c|}{ Pengalaman } \\
\hline & Teknis Peliputan Online & Sentimen masa aksi & Intimidasi \\
\hline Informan 1 & $\begin{array}{l}\text { 1. Mobilitas wartawan } \\
\text { 2. Jaringan komunikasi } \\
\text { susah } \\
\text { 3. kepekaan terhadap nilai } \\
\text { berita }\end{array}$ & $\begin{array}{l}\text { Merasakan sentimen massa } \\
\text { terhadap wartawan Detik. } \\
\text { com }\end{array}$ & $\begin{array}{l}\text { Menjadi saksi mata atas } \\
\text { intimidasi terhadap wartawan } \\
\text { saat aksi Bawaslu }\end{array}$ \\
\hline Informan 2 & $\begin{array}{l}\text { 1. Mobilitas wartawan } \\
\text { 2. Peka akan nilai berita } \\
\text { 3. Siap siaga (standby) }\end{array}$ & $\begin{array}{l}\text { Merasakan sentimen massa } \\
\text { terhadap wartawan Detik. } \\
\text { com }\end{array}$ & $\begin{array}{l}\text { Menjadi saksi intimidasi } \\
\text { terhadap saat aksi Bela } \\
\text { Tauhid dan Munajat } 212\end{array}$ \\
\hline Informan 3 & $\begin{array}{l}\text { 1. Mobilitas wartawan } \\
\text { 2. Kebugaran fisik }\end{array}$ & $\begin{array}{l}\text { Merasakan sentimen massa } \\
\text { terhadap wartawan Detik. } \\
\text { com }\end{array}$ & $\begin{array}{l}\text { Mengalami intimidasi saat } \\
\text { aksi Bela Tauhid dan Munajat } \\
212\end{array}$ \\
\hline Informan 4 & $\begin{array}{l}\text { 1.Peka akan nilai berita } \\
\text { 2.jaringan komunikasi } \\
\text { susah } \\
\text { 3. mobilitas wartawan }\end{array}$ & $\begin{array}{l}\text { Merasakan sentimen massa } \\
\text { terhadap wartawan Detik. } \\
\text { com }\end{array}$ & - \\
\hline Presentase & $100 \%$ & $100 \%$ & $100 \%$ \\
\hline
\end{tabular}

Sumber: Hasil penelitian peneliti, Juli 2019

Dalam paparan Madrim, terjadinya kekerasan juga bisa dikarenakan kurangnya pemahaman terkait cara kerja jurnalistik oleh pelaku baik dari kerja teknis atau etika peliputan. Merujuk dari pengakuan informan, saat masa awal bergabung mereka memang langsung di lepas ke lapangan tanpa dibekali pelatihan tentang jurnalistik. Informan lantas memahami kerja jurnalistik saat bertugas di lapangan dengan arahan kantor dan interaksi dengan sesama wartawan. Situasi tersebut membuat wartawan mempelajari konsep ideal dari jurnalistik 
pada konstruksi wartawan lainnya, bukan dalam tataran ideal. Pada tahap awal, wartawan mengeskternalisasi dirinya sehingga kemudian bertemu dengan produk-produk manusia yakni etika dan cara peliputan, para informan lantas menyesuaikan dengan produk-produk tersebut wartawan pada umumnya. Dalam sistem tersebut, para informan tidak mendapatkan pemahaman ideal bagaimana meliput berita atau menyelamatkan diri saat situasi rusuh.

Peneliti akan mengelaborasi lebih soal pemahaman wartawan tentang etika jurnalistik sebagai contoh. Para informan memilik pemahaman yang berbeda-beda soal etika pada saat peliputan. Informan 1 memahami etika sebagai kebenaran dalam menghasilkan berita. Informan 4 menganggap etika merupakan tanggung jawab editor karena ia yang berwenang menaikkan berita. Informan 2 memahami etika sebagai proses wartawan mencari fakta di lapangan yang mengutamakan izin dan sopan santun kepada narasumber. Sedangkan Informan3 menyatakan bahwa dirinya memahami etika jurnalistik dari pembacaan terhadap pedoman pemberitaan media siber.

Dari jawaban tersebut terlihat bahwa tidak ada jawaban yang merujuk pada penerapan kode etik. Keempat informan mengaku mempelajari etika dari arahan kantor dan interaksi dengan wartawan lain. Tidak ada jawaban informan yang merujuk pada penerapan kode etik jurnalistik. Kondisi informan yang bergabung kepada Detik.com karena motif pekerjaan membuatnya tunduk pada kantor dan memunculkan motif sebab dan supaya saat meliput yakni melaksanakan tugas.

Permasalahan etika pemberitaan bukan merupakan permasalahan baru bagi media Detik.com. Pada kasus pemberitaan tewasnya WNI di Mesir misalnya terjadi salah informasi karena adanya kesalahan dalam mekanisme verifikasi pemberitaan. Kondisi tersebut menunjukkan problem etika dimana media tidak memberitakan peristiwa dengan akurat karena mementingkan kecepatan (Aninditya, A. W., Dadang, R. H., \& Supriadi, 2012). Penelitian tersebut menunjukkan adanya pengabaian etika jurnalistik oleh kantor yang berpengaruh pada kerja wartawan di lapangan.

Menurut AJI, salah satu solusi untuk meminimalisir potensi intimidasi kepada wartawan saat peliputan Aksi Massa 212 adalah meningkatkan kompetensi wartawan (Madrim, 2019). Wartawan harus dibekali dengan pelatihan berkala dan diuji setiap usai pelatihan. Hal tersebut menurut AJI tidak nampak dilakukan oleh media di Indonesia. Wartawan juga tidak memiliki kesadaran untuk melakukan uji kompetensi tersebut.

Pengalaman para informan dalam menghadapi tantangan peliputan Aksi Massa 212 terbagi menjadi teknis peliputan, sentimen massa aksi dan intimidasi pada wartawan. Ketiga tantangan pengalaman tersebut didapatkan wartawan proses peliputan berlangsung. Wartawan mengalami tiga proses simultan yakni eksternalisasi - objektivasi - eksternalisasi (Berger, P. L., \& Luckmann, 1990). Dengan membawa cadangan pengetahuan, wartawan Detik.com berinteraksi dengan dunia sosio-kultural massa aksi dalam tahap objektivasi dimana terjadi proses penting pembuatan tanda (Bungin, 2007).

Dalam konteks menghadapi tantangan di dunia sosio-kultural, informan membuat beberapa tanda. Pertama, tantangan teknis peliputan ; mencari ruang ketika susah sinyal dan menggunakan pelindung diri saat peliputan (misal menggunakan topi). Kedua, menghadapi sentimen massa aksi ; menggunakan pakaian dan atribut 212, berperilaku tidak mencolok, dan menyembunyikan kartu pers. Ketiga, menghadapi tantangan intimidasi; wartawan mementingkan keselamatan diri. Tanda-tanda tersebut kemudian diserap kembali oleh wartawan pada tahapan internalisasi dan menjadi cadangan pengetahuan baru untuk meliput aksi massa 212 selanjutnya. 
Bagan 1. Pengalaman Wartawan Detik.com dalam meliput aksi massa 212.

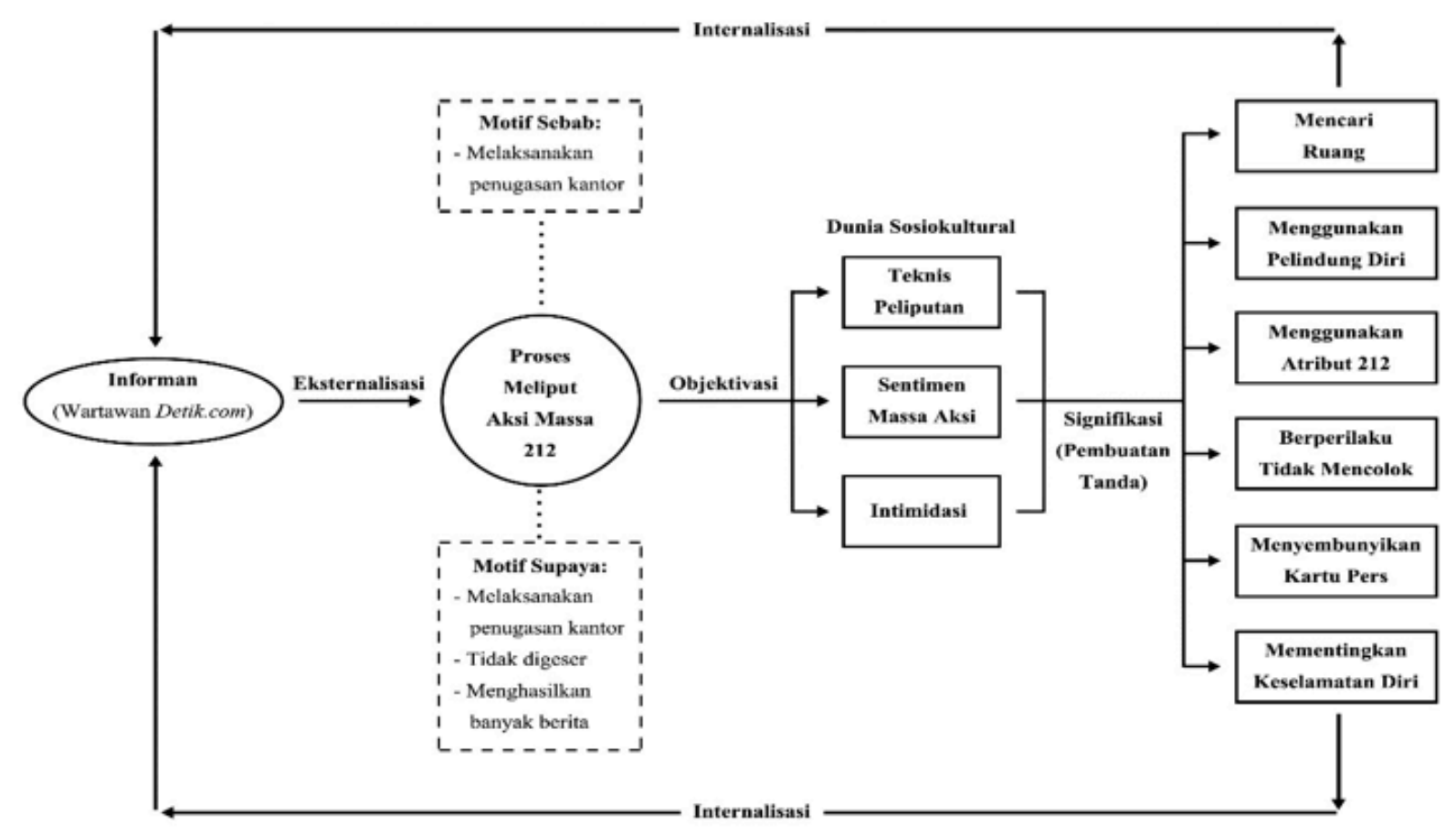

\section{Makna Aksi Massa 212 bagi Wartawan Detik.com}

Aksi massa 212 yang dimaksud dalam penelitian ini adalah aksi massa yang memiliki keterkaitan secara historis dengan Aksi 212 dan kelompok persudaraan Alumni 212 (PA 212). Pembatasan ini dimaksudkan untuk memberikan fokus pada permasalahan yang coba dijawab yakni makna aksi massa 212 bagi wartawan Detik.com.

Selain itu, penggunaan istilah aksi massa 212 dalam penelitian ini juga merujuk kepada istilah yang dipahami oleh wartawan. Hasil observasi lapangan menunjukkan wartawan kerap menggunakan istilah massa 212, merujuk pada massa yang sedang beraksi. Penggunaan tersebut terdapat dalam obrolan sesama wartawan dan tidak masuk ke dalam produk jurnalistik yang mereka hasilkan. Istilah tersebut juga peneliti gunakan untuk menggali pemaknaan wartawan pada aksi-aksi mobilisasi massa Islam yang kerap terjadi meski dengan tujuan berbeda-beda.

Konstruksi penggunaan istilah aksi massa 212 merujuk pada pengalaman liputan yang repetitif. Keempat informan menemui simbol 212 atau massa yang menggunakan atribut 212/ alumni 212. Hal tersebut menunjukkan istilah aksi massa 212 juga berasal dari konstruksi wartawan atas peliputan aksi mobilisasi massa Islam yang dijalani secara repetitif. Sosialisasi antar wartawan pun turut berpangaruh sebagai sosialisasi sekunder.

Para informan memaknai aksi massa 212 sebagai sebagai aksi yang bertujuan politik dengan membawa nama agama. Informan1, Informan2, dan Informan4 memberikan pemaknaan tambahan bahwa terjadi pergeseran dari Aksi 212 (2016) yang benar-benar membela agama sampai aksi massa lanjutan yang bergeser pada tujuan politik. Informan 2 menambahkan makna damai dengan mengacu pada pengamatannya pada aksi yang berlangsung damai. Pada konteks kerusuhan, Informan 2 membedakannya sebagai massa perusuh bukan massa aksi. Sementara Informan3 menganggap bahwa Aksi 212 dari awal hingga kini memiliki tujuan yang sama.

Pemaknaan akan dunia sosial bermula dari pemikiran Max Weber tentang tindakan sosial. Weber mengemukakan bahwa pengalaman dan perilaku manusia (human being) bermakna secara sosial (socially meaningful reality). Alfred Schutz menyebut bahwa terdapat penekanan pada prinsip tindakan sosial (social action), konsep sosial didefinisikan sebagai hubungan dua 
orang atau lebih, sedangkan konsep tindakan didefinisikan sebagai perilaku yang membentuk makna subjektif. Posisi makna subjektif berada dalam dunia sosial, oleh karenanya terdapat kesamaan dan kebersamaan di antara para aktor. Oleh karenannya, makna subjektif lantas disebut juga sebagai makna intersubjektif (Kuswarno, 2013).

Konsep tentang makna subjektif tersebut juga bekerja pada keempat informan. Mereka memunculkan makna politik dengan membawa agama karena interaksi dengan aktor dalam dunia sosial. Aktor dalam konteks ini merupakan massa aksi yang mereka temui, wartawan mereka ajak mengobrol, teman berdiskusi, orator yang mereka wawancarai, akademisi yang mereka minta pendapat atau dari tokoh politik yang mereka ketahui, Atas interaksi tersebut mereka berbagi pengalaman subjektif sehingga tercipta pemaknaan intersubjektif yang sama pada keempat informan yakni aksi politik dengan narasi agama.

Schutz lantas mengungkapkan bahwa makna intersubjektif harus ditilik dari sudut pandang historis. Melihat ke depan (looking-forward into the future) dan masa lalu (past-ness) merupakan faktor yang mempengaruhi tindakan dan makna seseorang (Kuswarno, 2013). Oleh karenanya, peneliti coba melihat latar belakang informan dalam melihat struktur pemaknaan yang dimiliki.

Pemaknaan lain yang diungkapkan oleh informan adalah adanya pergeseran makna dari murni bela agama pada awal kemunculan menjadi aksi politik membawa agama. Tiga informan yang menungkapkan pergeseran makna tersebut antara lain Informan1, Informan2, Informan4. Peneliti melihat ada faktor masa lalu yang merujuk pada masa sebelum menjadi wartawan yang berpengaruh pada pemaknaan tersebut.

Informan1 tumbuh dan besar di desa dengan pengaruh lingkungan pesantren yang kuat. Ia mengaku juga tidak nyaman saat ada penistaan agama oleh Ahok pada awal kemunculan aksi ini. Informan2 juga tinggal di lingkungan yang religius meskipun ia mengaku lebih banyak mendapatkan pemahaman agama saat berdiskusi dengan rekan kampusnya. Informan4 tinggal di lingkungan perkotaan dengan penduduk heterogen dengan mendapatkan pengajaran agama dari TPA saat masih kecil.

Menurut Berger dan Luckmann (1990), individu mengalami dua tahap sosialisasi yakni sosialisasi primer dan sekunder. Sosialisasi primer terjadi saat masa kanak-kanak yang membuat individu berhasil masuk ke dalam masyarakat. Sosialisasi sekunder merupakan tahapan lanjutan yang membuat individu masuk ke dalam sektor-sektor baru dalam dunia objektif masyarakat.

Ketiga informan juga mendapatkan sosialisasi primer saat masih kanak-kanak. Dalam konteks kemunculan makna adanya pergesaran, maka peneliti melihat ada faktor sosialisasi primer. Lingkungan tempat mereka tumbuh dan berkembang berpengaruh pada diri mereka sebagai masyarakat. Ketiganya mengaku mendapatkan pengajaran agama saat masih kanakkanak. Bekal tersebut bertambah saat informan menjalani sosialisasi sekunder dimana proses sosialisasi sekunder. Informan2 misalnya, ia banyak berdiskusi bersama teman-temannya selama menjadi mahasiswa. Hal tersebut menambah wawasan Informan2 soal agama.

Berbeda dengan Informan3 yang berasal dari latar belakang keluarga yang heterogen. Anggota keluarga besarnya memeluk beberapa agama yang berbeda. Saat kanak-kanak, Informan3 mengaku pernah mendapatkan pengajaran dari Sekolah Katholik. Baginya agama merupakan urusan privat setiap orang. Proses tersebut merupakan proses sosialisasi primer Informan3. Sementara proses sosialisasi skunder Informan3, khususnya tentang isu agama, diakuinya berlangsung saat Informan3 menjalani perkuliahan di jurusan Ilmu Pemerintahan Unpad. Disana ia mengaku mendiskusikan aksi massa 212 sebagai gerakan politik semata. Pandangan tersebut tidak berubah karena tidak ada perbedaan dengan proses sosialisasi primer yang dia miliki. 
Penjelasan sebelumnya menjadi dasar bahwa informan memiliki dasar pengetahuan soal agama Islam yang membuat mereka turut tersinggung atas penistaan agama oleh Ahok. Oleh karenanya, mereka menyebut pemaknaan pergeseran tujuan aksi dari awalnya membela agama menjadi bertujuan politik. Sedangkan makna politik tersebut didapatkan dari interaksi yang mereka lakukan di dunia intersubjektifitas serta sosialisai sekunder yang mereka alami. Berbeda halnya dengan Informan3 yang memiliki pemaknaan tetap bawah dari pertama kemunculan Aksi Massa 212 hingga aksi-aksi selanjutnya hanya bermakna politik. Hal tersebut bisa dipahami sebagai faktor dari sosialisasi primer dan sekunder Informan3 yang tidak berhubungan kuat dengan faktor keagamaan.

Selain itu, tiga makna yang muncul dari para informan tentang makna Aksi Massa 212 juga dipengaruhi rutinitas peliputan. Informan dalam penelitian ini setidaknya pernah dua kali meliput Aksi Massa 212. Informan1 yang merupakan wartawan muda saja telah meliput lima aksi massa yang berbeda, Saat meliput aksi massa informan mengalami tiga tahapan simultan eksternalisasi - objektivasi - internalisasi (Berger, P. L., \& Luckmann, 1990). Informan melakukan proses internalisasi atas pertukaran tanda yang dilakukan pada dunia intersubjektifitas. Sederhananya, pengalaman meliput wartawan di lapangan lantas ditarik kembali ke dalam diri informan. Interaksi informan dengan massa aksi memberi pengetahuan mereka soal motif politik dari massa. Mereka tidak terjebak dengan semangat membela agama yang ditujukan massa pada setiap aksinya.

Makna politik yang diungkapkan wartawan coba peneliti elaborasi lebih jauh. Peneliti melihat pamaknaan wartawan terhadap Aksi 212 dengan makna politik yang membawa agama relevan dengan konsep populisme Islam. Populisme secara mendasar didefinisikan sebagai adanya gerakan rakyat kebanyakan (the people) mengkonfrontasi segelintir penguasa (the elites) (Wejnert, 2014). Sedangkan menurut Vedi Hadiz, populisme Islam merupakan gerakan/ aliansi yang terbentuk dari beragam kelas yang asimetris (koalisi multikelas) dengan massa yang heterogen. Perbedaan antar kelas tersebut lantas hilang dan disatukan oleh narasi simbol keagaman tertentu yang dalam konteks ini adalah ummah. Narasi ummah menjadi representasi dari The People yang bergerak melawan para elit yang pada akhirnya berhasil memobilisasi massa dalam jumlah besar untuk melakukan aksi (Kusumo, R., 2018)

Penguatan fenomena populisme Islam pada akhirnya bergantung pada seberapa kuat isu tersebut tampil di ruang publik nasional. Lantas terdapat dua perbedaan rujukan term yang kerap digunakan dalam ruang publik yakni umat dan ummah (Jati, 2016). Penggunaan umat merujuk pada bentuk ekspresi Islam yang berbasis isu dan simbol atas nama kepentingan umat seperti Aksi Bela Islam dan Aksi Bela Ulama. Sedangkan narasi ummah mengacu pada gerakan politik misalnya Menuju NKRI Bersyariah, Khalifah Indonesia, dan sebagainya.

Dalam konteks jurnalistik, keempat informan mengaku tidak ada pengaruh antara pemaknaan mereka dengan produksi berita. Para informan kompak menyatakan bahwa mereka memberitakan apa adanya berdasarkan fakta lapangan. Peneliti lantas mengecek penggunaan narasi yang dibuat oleh Detik.com dengan acuan pandangan perbedaan term umat dan ummah. Pengecekan dilakukan secara sederhana dengan mengetik keyword umat dan ummah. Hasil yang penulis dapat adalah pemberitaan Detik.com tentang Aksi Massa 212 dan PA 212 yang sejatinya merupakan konsep politik menurut Hadiz dan Wejnert. Padahal narasi umat memiliki acuan dari kepentingan agama.

Dalam konteks tersebut, muncul dua kondisi yang memungkinkan terkait implikasi pemaknaan pada pemberitaan Detik.com terhadap Aksi Massa 212. Pertama, memang tidak terdapat pengaruh antara pemaknaan wartawan Detik.com pada pemberitaan aksi massa 212. Dengan kata lain, wartawan memberitakan sesuai fakta dan dengan sengaja memunculkan 
narasi umat. Kedua, terdapat kemungkinan bahwa wartawan tidak memiliki pemahaman terkait perbedaan narasi umat dan ummah di dalam ruang publik. Sejatinya, kebenaran dari dua kemungkinan tersebut membutuhkan riset lebih jauh yang fokus membahas pengaruh hirarki media dalam pemberitaan Detik.com pada Aksi Massa 212.

Pemaknaan tersebut dilihat dari sudut pandang kesadaran dan kesengajaan informan. Schutz mengungkapkan bahwa indvidu memaknai suatu tindakan tidak terlepas dari gambaran kesadaran yang ada dipikirannya. Makna terbentuk ketika seseorang merefleksikan pengalaman atas aksinya dan tindakan nyata yang terjadi. Hal tersebut dapat diamati peneliti fenomenologi dalam proses observasi (Schutz, 1967). Kesadaran akan penugasan kantor, gambaran aksi massa 212 dan kondisi lapangan terkumpul dalam pengalaman yang kemudian dimaknai reflektif oleh para informan.

Kembali ke pertanyaan awal tentang pemaknaan wartawan Detik.com terhadap Aksi Massa 212. Peneliti melihat bahwa pemaknaannya adalah Aksi politik membawa agama; terjadi pergeseran dari aksi awal; dan aksi damai sebagai hasil dari sosialisasi primer, sekunder, serta proses internalisasi informan setelah mengalami pertukaran makna pada dunia intersubjektivitas. Pemaknaan tersebut membentuk rantai makna yang turut mempengaruhi tindakan wartawan Detik.com dalam meliput aksi massa 212. Penelitian juga tidak menunjukkan bercampurnya pemaknaan dengan produk pemberitaan Detik.com oleh para informan, mereka menggunakan narasi yang digunakan massa saat aksi berlangsung

Bagan 2. Pemaknaan wartawan Detik.com tentang aksi massa 212.

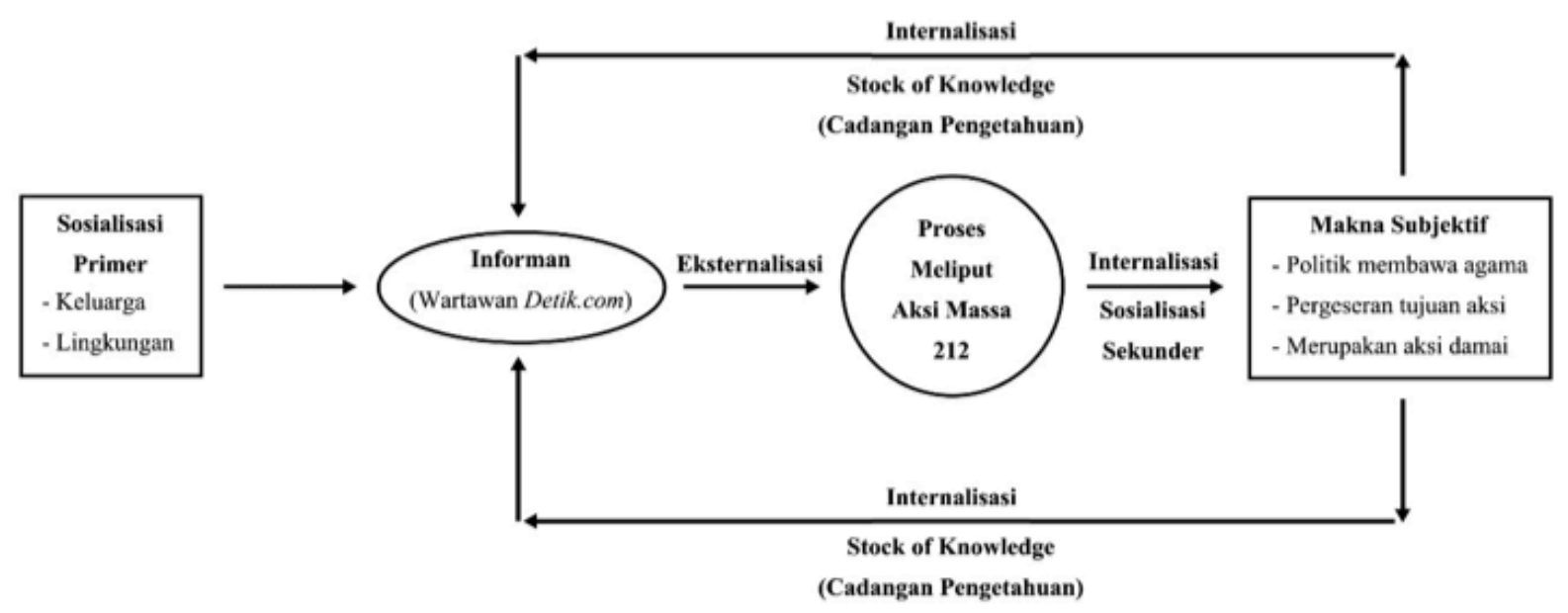

\section{SIMPULAN}

Wartawan Detik.com mendapatkan pengalaman tantangan peliputan Aksi Massa 212 yaitu teknis peliputan, sentimen massa dan intimidasi pada tahap objektivasi. Pada tahap tersebut, wartawan Detik.com masuk dalam dunia intersubjektifitas dimana melakukan penyesuaian dan pembuatan tanda. Dalam konteks peliputan Aksi Massa 212, wartawan Detik.com membuat tanda atas tantangan yang dihadapi yaitu bergerak mundur, menggunakan topi, menggunakan atribut 212, berperilaku tidak mencolok, menyembunyikan kartu pers dan mementingkan keselamatan diri.

Makna Aksi Massa 212 bagi wartawan Detik.com adalah politik membawa agama, pergeseran tujuan Aksi dan merupakan aksi damai. Makna-makna tersebut didapat atas pengalaman peliputan yang reflektif dengan kesadaran gambaran liputan yang ada di pemikiran mereka. Dengan kata lain, kita dapat menyebut bahwa tiga makna tersebut muncul atas kesadaran dan kesengajaan para informan atas fenomena yang mereka lalui. Mereka 
Volume 03 Nomor 02 Tahun 2020

DOI: $10.24198 / \mathrm{jkj} . \mathrm{v} 3 \mathrm{i} 2.25487$

mengaku pemaknaan mereka tidak bercampur dengan karya jurnalistik yang dihasilkan karena kesengajaan dan kesadaran mereka atas penugasan kantor yang mengikat mereka.

Peneliti merekomendasikan wartawan Detik.com untuk meningkatkan stock of knowledge dalam dirinya bukan hanya dari pengalaman selama meliput di lapangan namun juga dari berbagai sumber lain. Peneliti menyarankan wartawan Detik.com untuk banyak mempelajari teknik dan etika dalam jurnalistik sehingga wartawan mengetahui konteks ideal penerapan jurnalis.

\section{DAFTAR PUSTAKA}

Aninditya, A. W., Dadang, R. H., \& Supriadi, D. (2012). Etika dan Prinisip Jurnalisme Media Siber Detik.com Mengenai Mekanisme Pemberitaan Tewasnya WNI di Kerusuhan Mesir. EJurnal Mahasiswa Universitas Padjadjaran.

Berger, P. L., \& Luckmann, T. (1990). Tafsir Sosial Atas Kenyataan. Jakarta: LP3ES.

Bungin, B. (2007). Penelitian Kualitatif : Komunikasi, Ekonomi, Kebijakan Publik, dan Ilmu Sosial Lainnya. Jakarta: Kencana.

CNN. (2019). Polisi Tangkap 300 Perusuh Aksi 22 Mei.

DH, A. (2016). AJI Kecam Peserta Demo 212 yang Serang Jurnalis Metro TV.

Gusti Ramadan Alhakki. (2019). Wawancara Gusti Ramadan Alhakki. Jakarta.

Jati, W. R. (2016). Dari Umat Menuju Ummah ? Melacak Akar Populisme Kelas Menengah Muslim Indonesia. Maarif Arus Pemikiran Islam Dan Sosial.

Kovach, B., \& Rosentiel, T. (2001). The Elements of Journalism. Jakarta: Pantau.

Kusumo, R., \& H. (2018). Populisme Islam di Indonesia : Studi Kasus Aksi Bela Islam oleh GNPF-MUI Tahun 2016-2017. Jurnal Politik.

Kuswarno, E. (2013). Fenomenologi : Metode Penelitian Komunikasi. Bandung: Widya Padjadjaran.

Lim, M. (2017). Freedom to Hate : Social Media, Alghoritmic, Enclaves, and Rise of Tribal Nationalism in Indonesia. Critical Asia Studies, 9.

Madrim, S. (2019). Kekerasan Wartawan pada Aksi Massa 212.

Margianto, J., \& Syaefullah, A. (2012). Media Online : Pembaca, Laba, dan Etika. Jakarta: Divisi Penyiaran dan Media Baru AJI Indonesia.

Moleong, L. D. (2010). Metodologi Penelitian Kualitatif: Edisi Revisi. Bandung: Rosda Karya.

Pratiwi, F. (2019). Jumlah Peserta Aksi 212 Mencapai 75 Juta Orang.

RSF. (2019). Only Nine Percent of Humandkind Lives in a Country Where Press Freedom is Good.

Schutz, A. (1967). The Phenomenology of Social World. United States of America: Northwestern University.

Ward, M. (2002). Journalism Online. Oxford: Focal Press.

Wejnert, B. (2014). Populism and Democracy: Not The Same but Interconnected, in The Many Faces of Populism: Current Perspective. Emerald Insight.

Yanuary, D. A., \& Gumilar, G. (2019). Konstruksi Realitas Wartawan Pikiran Rakyat Mengenai Pengarusutamaan Isu Lingkungan. Jurnal Kajian Jurnalisme, 1(2). https:// doi.org/10.24198/jkj.v1i2.21341 